\title{
THE MEDIATION EFFECT OF SELF-ESTEEM ON THE RELATIONSHIP BETWEEN PERSONALITY TRAITS AND COLLECTIVE SELF-ESTEEM IN THE SAMPLE OF LATVIAN ARTS THERAPISTS
}

\author{
Zane Krieḳe \\ Rīga Stradiņš University, Latvia \\ Kristīne Mārtinsone \\ Rīga Stradiņš University, Latvia \\ Viktorija Perepjolkina \\ Rīga Stradiņš University, Latvia
}

\begin{abstract}
The purpose of this study was to examine the relationship among personality traits, self-esteem and collective self-esteem of Latvian Arts therapists and specifically to examine a potentially mediating role of self-esteem on the correlation between personality traits and collective self-esteem. The sample of the study consisted of 81 Arts therapists of whom data for 74 AT were analysed. The data were collected by Latvian Personality Inventory (LPI-v3), Collective Self-Esteem Scale (CSES), Rosenberg Self-Esteem Scale (RSES) including the demographic data. Pearson correlations indicated significant negative moderate correlation between self-esteem and LPI scale Neuroticism, positive moderate correlation between selfesteem and CSES scale Membership self-esteem and between LPI scale Neuroticism and CSES scale Membership self-esteem, therefore mediation analysis was applied to examine the effect of self-esteem on a relationship between Neuroticism and Membership Self-Esteem. Sobel test was used to test the significance of a mediation effect. Results indicated Self-esteem as a significant mediator in the relationship between Neuroticism and Membership self-esteem. The findings of this research suggest that emotional stability and self-esteem influence Latvian Arts therapist's sense of identifying themselves as members with their professional group. These results are important for further development of Latvian Arts therapist profession to strengthen Art therapist's professional identity.
\end{abstract}

Keywords: arts therapists, personality traits, self-esteem, collective self-esteem.

\section{Introduction}

The profession of Arts therapists' in Latvia has experienced rapid growth over different time periods, including various changes in the legal framework and the curriculum. Each period marks differences in the professional activities, for example changes in occupational status, therefore generating several generations of Latvian Arts therapists (Mārtinsone, 2016). Thus, Arts therapist's perspective 
about their status and role has developed according to the specifics of each time period which were influenced by the political and economic situation in the country, cultural and artistic traditions, human resources and availability, as well as existing legal regulations (Mārtinsone, Mihailova, Mihailovs, MajoreDūšele, \& Paipare, 2008). Due to the previously mentioned various changes in the profession's development, Arts therapists regarding their professional group can describe themselves by using " $I$ " or "We" title, and therefore a question arises to what extent these titles are related. Thus, the intention of this article is to discuss the links between individual and social factors which influence the sense of belonging to the professional group. The connection between personality traits and profession have been widely discussed in the literature (Edwards, 1991; Kristof-Brown, 2007), as well as the importance of the collective self-esteem in terms of occupational level (Yu, 2008). Moreover, self-esteem is one of the phenomena related to the "I" concept, for example, to personality traits (Weidmann, Lederman, Robins, Gomez, \& Grob, 2018), as well as to "We" or the collective identity (Sharma \& Agarwala, 2013), but there is a lack of research studying the relationships among these three concepts.

Personality traits are defined as dimensions that characterize differences in thinking, feelings, and action of an individual (Costa \& McCrae, 1992). The FiveFactor Model, its analogue based on the lexical studies - The Big Five model (Goldberg, 1990), and the HEXACO model (Lee \& Ashton, 2004) are most used in the research to conceptualize human personality. Personality factors within the Five-Factor Model include Neuroticism, Openness, Extraversion, Agreeableness and Conscientiousness whereas HEXACO model as personality characteristics include Extraversion, Emotionality, Openness to Experiences, Agreeableness, Conscientiousness and Honesty - Humility. One of the definitions of personality traits distinguish that "Personality traits are the relatively enduring patterns of thoughts, feelings, and behaviors that reflect the tendency to respond in certain ways under certain circumstances” (Roberts, 2009, p.140). Although personality traits are considered as relatively stable factors, though traits can change through different stages of life (Roberts, Walton, \& Viechtbauer, 2006) because of life experiences and sociocultural environments, clinical and subclinical trials and intentional interventions (Allemand \& Fluckiger, 2017). Moreover, changes might occur in different levels (Wruzs \& Roberts, 2016) including broad level traits (e.g. Neuroticism), habits and the states level. Theoretical models suggest bidirectional relations among these levels which means changes can occur both on traits and states level.

Collective self-esteem refers to the one's perception of the importance of membership in a social group as well as to the value of membership and emotional significance of belonging to this group (Luhtanen \& Crocker, 1992; Butler \& Constantine, 2005) and collective self-esteem is part of the collective identity 
phenomenon. Authors have been defined four aspects of collective self-esteem. Private collective self-esteem characterizes an individual's satisfaction with belonging to a particular social group whereas public collective self-esteem reflects to the social assessment of the social group. The importance of identity describes the extent to which membership of a social group is linked to an individual's personal identity. Membership self-esteem illustrates the sense of the value and significance within a social group. One of the research question scholars have paid attention, is collective self-esteem and job satisfaction for professionals. In fact, collective self-esteem has been recognized as a mediator between job satisfaction and burnout (Yu, 2008). Research of Korean music therapists' collective self-esteem, job satisfaction, and burnout concluded that higher scores on collective self-esteem lead to higher job satisfaction, therefore reducing level of burnout (Kim, 2012). It should be noted that an important aspect of the collective self-esteem studies is the multidisciplinary team and the clarity of roles within the team. Results indicate that music therapists working within the multidisciplinary team show higher rates on the level of burnout than non-team therapists (Hills, Norman, \& Forster, 2000).

Self-esteem implies as "individual's subjective evaluation of his or her worth as a person” (Donnellan, Trzesniewski, \& Robins, 2011, p. 718). More than half century ago sociologist Morris Rosenberg developed self-esteem scale (Rosenberg, 1965) which is widely used measure nowadays in science. Low selfesteem is associated with one's negative assertiveness towards self-concept (Cast \& Burke, 2002) therefore correlating to several negative outcomes such as depression (Zeigler-Hill, 2011). Moreover, in a research study by Donnellan and colleagues (2005) it was concluded that low self-esteem might predict potential externalized problems in future. This means that individual with low self-esteem might experience several problematic issues across forthcoming lifetime periods. In opposite, high self-esteem individuals perceive themselves as worth human beings which leads to satisfying work life (Kuster, Orth, \& Meier, 2013), stronger mental health (Tracy, Cheng, Robins, \& Trzesniewski, 2009), social relationships (Baumeister, Campbell, Krueger, \& Vohs, 2003) etc. Moreover, the level of selfesteem might be related to individual's subjective feeling about being rejected or in contrast - being acceptant (DeHart, Pelham, \& Murray, 2004).) Thus, selfesteem influences one's ability to build a relationship with peer colleagues and moreover, to sense the feeling of becoming a member of a social group.

Personality traits and self-esteem has been a broadly discussed research topic among scholars (Weidmann et al., 2018) and it was shown that individuals with a higher self-esteem are more emotionally stable (low neuroticism), more extravert and conscious. Moreover, there has been found a positive correlation of selfesteem and collective self-esteem (Sharma \& Agarwala, 2013). Thus, it can be assumed that there might be interrelation between neuroticism, extraversion, 
consciousness, self-esteem and collective self-esteem. Regarding employment, individuals belong to particular social group, creating positive or negative selfesteem of this group, which is also known as a collective self-esteem, and this might influence the ability to identify oneself of who I am as a professional. As mentioned before, Latvian Arts therapists might differ in terms of education, curriculum, legal status, and therefore it is important to understand the factors, which might interfere their ability to define themselves to a new professional group. The sense of "who am I" can change through several stages of one's life span. Therefore, it can be assumed that sense of "who am I" as a professional also might change through developmental processes. Instead of discussing the formation of personal or collective identity, this paper focuses on the links between these two forms of identity. The purpose of this study was to examine the relationship among personality traits, self-esteem and collective self-esteem of Latvian Arts therapists (AT) and specifically to examine a potentially mediating role of self-esteem on the correlation between personality traits and collective self-esteem.

The main questions of this study are:

(1) What is the relationship between self-esteem and aspects of the collective self-esteem in the sample of Latvian Arts therapists?

(2) What is the relationship between personality traits and the aspects of the collective self-esteem in the sample of Latvian Arts therapists?

(3) Is there a mediation effect of self-esteem on relationship between any personality trait and any aspect of the collective self-esteem in the sample of Latvian Arts therapists?

\section{Methods}

\section{Participants}

Participants were 81 Latvian Arts therapist and the data analysed for 74 AT (aged from 26 to 58 years). All surveys were valid for data analyses. Seven participants scored high on a Lie scale of LPA-v3 and they were excluded for further data analysis. Participants were Latvian Arts therapist who a) have the second level professional higher education in health care and professional qualification as Arts therapist specializing in one of the 4 specializations (arts, dance and movement, music, drama) or equivalent education and b) who are practicing as an Art therapist in one of the above mentioned specializations.

\section{Measures}

The Latvian Personality Inventory (LPA-v3; Perepjolkina \& Rengge, 2013) consists of 100 self-report items which are scored on a 5-point Likert scale ranging from 1 "strongly disagree" to 5 "strongly agree". LPA-v3 allows to assess six personality factors (Neuroticism, Extraversion, Openness to experience, 
Agreeableness, Conscientiousness and Honesty-Humility) and 24 facets. There are 16 items per each factor-scale, 4 items per facet-scale, and 4 additional items for Lie scale. Ratings were made on a 5-point Likert scale ranging from 1 comlpetely disagree to 5-completely agree. Cronbach's alpha values are between 0.81 and 0.90 .

Rosenberg Self-esteem Scale (Rosenberg, 1965; adapted from Latvian (Miltuze, 1996)) contains 10 statements, which can be rated from 1 "strongly agree" to 4 "strongly disagree". Maximum score 40; minimum - 10. A higher score indicates a higher self-esteem. Cronbach's alpha $0.84(\alpha=0.84)$.

The Collective Self-Esteem Scale (Luhtanen \& Crocker, 1992; adapted in Latvian (Ezerina, Kleina, Martinsone, \& Purvlice, 2018)) contains 16 statements measuring 4 subscales (Membership Self-Esteem, Private Collective Self-Esteem, Public Collective Self-Esteem, Importance to Identity). Each subscale consists of 4 statements which are scored by 7-point Likert scale ranging from 1 "strongly disagree" to 7 "strongly agree". Cronbach's alpha values are between 0.76 and 0.85 .

\section{Procedure}

The online survey was distributed to the Latvian Arts therapists with the assistance of professional associations - Latvian Arts therapies association union, Latvian Art Therapy Association, Latvian Dance Movement Therapy Association, Latvian Drama Therapy Association, Latvian Music Therapy Association. Professional associations received an email with information about the study (authors, aims, tasks, contact information, etc.) with a request to forward the online survey to their association members. Participants were informed about confidentiality, and each participant confirmed his / her agreement to participate in the study by completing the questionnaire. The participants were informed that the data would be processed and analysed in aggregate form.

\section{Research results}

The analyses started by detecting the correlations among the variables to find answers on the first two questions of the research. Table 1 presents the outcome of Pearson correlations analysis indicating, that self-esteem, as it was expected, positively weekly to moderately correlate with all aspects of the collective selfesteem, ranging from $r=.23 ; p>.05$ with Public Collective Self-Esteem to $r=.47 ; p<.01$ with Membership Self-Esteem.

As to the answer to the second question, results show, that Neuroticism is negatively strongly associated with self-esteem, moderately with Membership Self-Esteem and weekly with Private Collective Self-Esteem; Openness to Experience was found to be positively weekly correlated to the self-esteem, Memberships Self-Esteem and Importance to Identity, but Conscientiousness is 
weekly positively associated only with Self-Esteem and Importance to Identity aspect of the collective self-esteem. Agreeableness was found to be weekly positively associated only with self-esteem, bet no with any aspect of the collective self-esteem, and Honesty-Humility is not associated no with selfesteem, no with any aspect of the collective self-esteem.

Table 1 Correlations among personality traits, self-esteem and collective self-esteem

\begin{tabular}{|c|c|c|c|c|c|c|c|c|c|c|}
\hline Scale & 2. & 3. & 4. & 5. & $\mathrm{~N}$ & E & $\mathrm{O}$ & C & A & $\mathrm{H}$ \\
\hline 1. Self-Esteem & $.47^{* *}$ & .23 & $.31^{* *}$ & $.28^{*}$ & $-.68^{* *}$ & .18 & $.30^{* *}$ & $.27^{*}$ & $.27^{*}$ & .09 \\
\hline $\begin{array}{l}\text { 2. Membership } \\
\text { Self-Esteem }\end{array}$ & & $.33^{* *}$ & $.58^{* *}$ & $.44^{* *}$ & $-.45^{* *}$ & -.02 & $.26^{*}$ & .19 & -.03 & -.01 \\
\hline $\begin{array}{l}\text { 3. Public Collective } \\
\text { Self-Esteem }\end{array}$ & & & $.63^{* *}$ & .18 & -.12 & .00 & -.06 & .13 & . 10 & -.05 \\
\hline $\begin{array}{l}\text { 4. Private } \\
\text { Collective Self- } \\
\text { Esteem }\end{array}$ & & & & $.36^{* *}$ & $-.24^{*}$ & .04 & .20 & .11 & .09 & .11 \\
\hline $\begin{array}{l}\text { 5. Importance to } \\
\text { Identity }\end{array}$ & & & & & -.19 & .17 & $.26^{*}$ & $.28^{*}$ & .06 & -.00 \\
\hline
\end{tabular}

Regarding the third question of this research and based on the results presented in the Table 1, Neuroticism is the only personality trait, which is strongly enough correlated with both self-esteem and membership self-esteem. Self-esteem has a positive moderate correlation to membership self-esteem $(r=.45 ; p<.01)$ and negative moderate correlation to Neuroticism $(r=-.68$; $p<.01$ ), whereas Membership Self-Esteem has a negative moderate correlation to Neuroticism $(r=-.45 ; p<.01)$. Therefore, self-esteem might be considered as a mediator between Neuroticism and Membership Self-Esteem. In order to examine this, Baron and Kenny (1886) mediation model was applied.

The results (see Fig.1) showed that Neuroticism significantly predicted SelfEsteem (B = -0.282, $\beta=-0.681, \mathrm{p}<.001)$ (path a); Self-Esteem had a significant impact on Membership Self-Esteem $(B=0.060, \beta=0.311, p<.05)$ after controlling the impact of Neuroticism (path b). Moreover, the total effect (path c) of Neuroticism on Membership Self-Esteem was significant $(\mathrm{B}=-0.036$, $\beta=-0.451, p<.001$ ). The direct effect (path c') of Neuroticism on Membership Self-Esteem vanished after controlling the impact of Self-Esteem $(B=-0.019$, $\beta=-0.240, \mathrm{p}=.091)$. Congruent with these results, the Sobel test indicated a 
significant mediation effect (Sobel test $=-2.137$, SE $=.008, p=.033$ ). Thus, findings support a model in which self-esteem fully mediated the relationship between Neuroticism and Membership Self-Esteem.
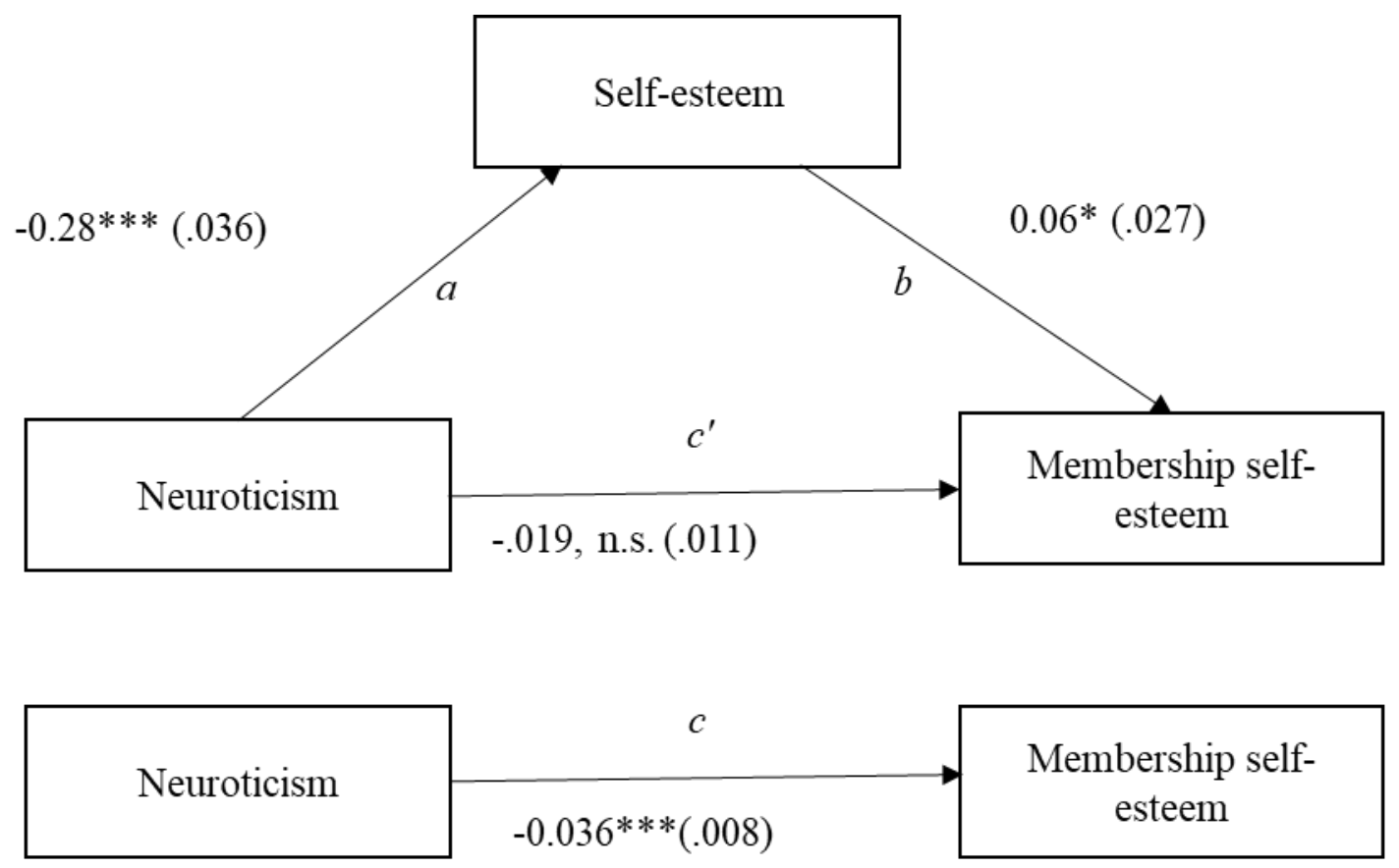

Figure 1 Mediation model for Neuroticism, Self-esteem and Membership self-esteem $N=74$. Values shown are unstandardized coefficients and standard errors in parentheses. ${ }^{* * *} p<.001 .{ }^{*} p<.05$

\section{Discussion}

The purpose of this study was to investigate the relationships among personality traits, self-esteem and collective self-esteem for Latvian Arts therapists. As results indicated significant moderate correlations among the above-mentioned variables, mediation analysis was applied which confirmed selfesteem as a mediator between LPI-v3 scale Neuroticism and CSES Membership Self-Esteem.

Regarding the purpose of this paper, data indicated several important aspects. Firstly, the findings of this study confirmed that emotional stability and selfesteem are interrelated, which means that individuals with higher self-esteem are more emotional stable and vice versa. Thus, it can be assumed that therapists should work on their emotional stability. However, as discussed in the introduction, changes in personality traits might occur in different levels, and most common the changes occur in states than traits level. It is not impossible to change the trait, but this might require more time and financial resources than changes in the stated level. Therefore, it might seem more effective to strengthen one's self- 
esteem, and there are several methods on how to do this, for example, supervisions, self-therapy, coaching, mentoring etc. Secondly, data indicated that individuals with higher self-esteem might also have stronger membership selfesteem. This has also been supported already in literature as individuals with higher self-esteem might be more active in building social relationships. This could mean that one's confidence in himself / herself could lead to the sense of value and significance for a membership of some social groups. Thus, Arts therapists who have enough self-confidence might have the same confidence about their profession and work, therefore it might be easier for them to identify themselves with their professional group members. In contrast, those Arts therapists with lower self-esteem, who are unsure about themselves and who question their worth, skills and abilities, might not identify with the professional group as they might feel as worthless members. Thirdly, data suggest that also emotional stability might relate to the sense of being a member of social group.

In terms of the interrelations, mediation analysis confirmed that therapist's sense of identifying himself / herself as a member of a group is related to personality and mediated by self-esteem. This means that strengthening therapist's self-esteem could support therapist's perspective choosing $I$ or We viewpoint when thinking about belonging to the professional group. As previously mentioned, Latvian Arts therapists have experienced rapid change through the development process of their profession. Thus, it would be important to strengthen their ability to identify themselves with their professional group.

The main limitation of this study is the relatively small sample size. The study can be repeated in larger sample size including more data analysis methods, for example, including qualitative methods.

Despite the limitations, the results of this study are important for the further development of Latvian Arts therapists profession to strengthen therapist's professional identity. One way on how to complete this could by strengthening their self-esteem as professionals. This is not only important in terms of their belonging to their professional group, but also regarding their daily work as previous research suggest that therapists with positive self-esteem, who know their worth, are more effective in work with clients and patients. Overall it can be concluded that individual factors as personality and self-esteem play a role in terms of therapist's identification with a social group. Therefore, not only social activities promote one's ability to feel a member of a team, but the focus should be also on individual factors. 


\section{References}

Allemand, M., \& Flückiger, C. (2017). Changing personality traits: Some considerations from psychotherapy process-outcome research for intervention efforts on intentional personality change interventions. Journal of Psychotherapy Integration, 27, 476-494.

Baron, R.M., \& Kenny, D.A. (1986). The moderator-mediator variable distinction in social psychological research: Conceptual, strategic, and statistical considerations. Journal of Personality and Social Psychology, 51, 1173-1182.

Baumeister, R.F., Campbell, J.D., Krueger, J.I., \& Vohs, K.D. (2003). Does high self-esteem cause better performance, interpersonal success, happiness, or healthier lifestyles? Psychological Science in the Public Interest, 4, 1-44.

Butler, S.K., \& Constantine, M.G. (2005). Collective self-esteem and burnout in Callero, P. (2015). Social Identity Theory. In The Blackwell Encyclopaedia of Sociology. Hoboken: John Wiley \& Sons.

Cast, A.D., \& Burke, P.J. (2002). A theory of self-esteem. Social Forces, 80, 1041-1069.

Costa, P.T. Jr., \& McCrae, R.R. (1992). The Five-Factor Model of Personality and Its Relevance to Personality Disorders. Journal of Personality Disorders, 6(4), 343-359.

Crocker, J., \& Park, L.E. (2004). The Costly Pursuit of Self-Esteem. Psychological Bulletin, 130(3), 392-414.

DeHart, T., Pelham, B., \& Murray, S. (2004). Implicit dependency regulation: Self-esteem, relationship closeness, and implicit evaluations of close others. Social Cognition, 22, 126-146.

Donnellan, M.B., Trzesniewski, K.H., Robins, R.W., Moffitt, T.E., \& Caspi, A. (2005). Low Self-Esteem Is Related to Aggression, Antisocial Behavior, and Delinquency. Psychological Science, 16(4), 328-335.

Edwards, J.R. (1991). Person-job fit: A conceptual integration, literature review, and methodological critique. In C. L. Cooper \& I. T. Robertson (Eds.), International review of industrial and organizational psychology. International review of industrial and organizational psychology, 1991, Vol. 6 (pp. 283-357). John Wiley \& Sons.

Ezerina, Z., Kleina, L., Mārtinsone, K., \& Purvlīce, B. (19.04.2018). Kolektīvā pašvērtējuma aptaujas adaptācija Latvijā: pētījuma 1.posms. Referāts prezentēts 4. Starptautiskā zinātniski praktiskajā konferencē "Veselība un personības attīstība: starpdisciplinārā pieeja”, Rīgā, Latvijā.

Goldberg, L.R. (1990). An Alternative "Description of Personality". The Big-Five Factor Structure. Journal of Personality and Social Psychology, 59(6), 1216-1229.

Hills, B., Norman, L., \& Forster, I. (2000). A study of burnout and multidisciplinary teamworking among professional music therapists. British Journal of Music Therapy, 14(1), $32-40$.

Kim, Y. (2012). Music therapists' job satisfaction, collective self-esteem, and burnout. Arts In Psychotherapy, 39(1), 66-71.

Kristof-Brown, A. (2007). Person-job fit. In S. Rogelberg (Ed.), Encyclopedia of industrial and organizational psychology (pp. 619-621). Thousand Oaks, CA: SAGE Publications.

Kuster, F., Orth, U., \& Meier, L.L. (2013). High self-esteem prospectively predicts better work conditions and outcomes. Social Psychological and Personality Science, 4, 668-675.

Lee, K., \& Ashton, M.C. (2004). Psychometric Properties of the HEXACO Personality Inventory. Multivariate Behavioral Research, 39(2), 329-358.

Luhtanen, R., \& Corcker, J. (1992). A collective self-esteem scale: Self-evaluation of one's social identity. Personality and Social Psychology Bulletin, 18, 302-318. 
Kriekse et al., 2020. The Mediation Effect of Self-Esteem on the Relationship Between Personality Traits and Collective Self-Esteem in the Sample of Latvian Arts Therapists

Mārtinsone, K., Mihailova, S., Mihailovs, I.J., Majore-Dūšele, I., \& Paipare, M. (2008). Mākslu terapija un tās attīstības konteksti (integratīvi eklektiskā pieeja Latvijā). Rīga: RSU.

Mārtinsone, K. (2016). Mākslu terapija cilvēku uzmeklē pati. No J. Duhovska un K. Mārtinsone (sast.), Mākslas terapijas izglìtības desmit gadi Rīgas Stradina universitātēe: No ieceres lìdz profesijai. Rīga: RSU.

Perepjolkina, V., \& Ren̨ge, V. (2013). Latvijas Personības aptauja (LPA-v3). Testa rokasgrāmata.

Roberts, B.W. (2009). Back to the future: Personality and assessment and personality development. Journal of Research in Personality, 43(2), 137-145.

Roberts, B.W., Walton, K.E., \& Viechtbauer, W. (2006). Patterns of mean-level change in personality traits across the life course: A meta-analysis of longitudinal studies. Psychological Bulletin, 132(1), 1-25.

Rosenberg, M. (1965). Society and the adolescence self-image. Princeton, N.Y.: Princeton University Press.

Sharma, S., \& Agarwala, S. (2015). Self-Esteem and Collective Self-Esteem Among Adolescents: An Interventional Approach. Psychological Thought, 8(1), 105-113.

Tajfel, H., \& Turner, J.C. (1979). An integrative theory of intergroup conflict, in The Social Psychology of Intergroup Relations (ed. W.G. Austin and S. Worchel), Brooks/Cole, Monterey, CA, pp. 33-47.

Tracy, J.L., Cheng, J.T., Robins, R.W., \& Trzesniewski, K.H. (2009). Authentic and hubristic pride: The affective core of self-esteem and narcissism. Self and Identity, 8, 196 -213.

Weidmann, R., Ledermann, T., Robins, R.W., Gomez, V., \& Grob, A. (2018). The reciprocal link between the Big Five traits and self-esteem: Longitudinal associations within and between parents and their offspring. Journal of Research in Personality, 74, 166-181.

Wrzus, C., \& Roberts, B.W. (2016). Processes of personality development in adulthood: The TESSERA framework. Personality and Social Psychology Review, 21(3), 253-277.

Yu, K., Lee, S.H., \& Lee, S.M. (2007). Counselor's collective self-esteem mediators job dissatisfaction and relationship with clients. Journal of Employment Counseling, 44(4), 163-172.

Zeigler-Hill, V. (2011). The connections between self-esteem and psychopathology. Journal of Contemporary Psychotherapy, 41, 157-164. 